\title{
Guest Editorial: A Perspective on Contradictory Revelations of Near-Death Experiencers
}

\author{
P. M. H. Atwater, L.H.D. \\ Charlottesville, VA
}

\begin{abstract}
In this editorial, I express my views on how to understand and reconcile contradictory revelations among near-death experiencers (NDErs). I address the issue of an NDEr proselytizing one's own unique interpretations in response to life's deepest questions.
\end{abstract}

KEY WORDS: near-death experience; revelations; proselytizing.

I can no longer avoid this topic: revelations from near-death experiencers (NDErs) that conflict with each other. Who's right? Who's off base? Whom should one believe? How can one resolve the dilemma when those who come back from the brink of death tell stories and hold views that are mutually contradictory?

People have quarreled over this matter for decades. Personally, over the years I've found myself repeatedly in the midst of such controversies. One version of it I've experienced is when NDErs, each with their own perspective, ask me to support them in the sales of their books by writing the Introduction-in essence, endorsing the validity of each of their unique perspectives. This matter of advocating-even proselytizing about-one's unique perspective on the NDE is so pervasive that I feel I must finally speak up and clarify what I believe to be at play.

P. M. H. Atwater is an NDEr and a free-lance investigator, author, lecturer, and workshop facilitator whose principal interest has been NDEs and spiritual transformation. Correspondence regarding this editorial should be sent to Dr. Atwater at P. O. Box 7691, Charlottesville, VA 22906-7691; e-mail: atwater@cinemind.com. 
In the mid 1970s, Raymond Moody's book, Life After Life, opened a mighty big door for millions of people worldwide. In the 1980s and 1990s it was quite easy for near-death researchers to publish their findings and for experiencers to publish their stories. A few of these sold quite well; some even became national and international bestsellers.

In the last few years, NDE research findings and other developments have converged to open a new level of focus, on subjects like consciousness and the brain, brain development and brain shift, and different views of out-of-body experiences and the afterlife. Yet, at a time of more amazing and pertinent material than ever before in the history of the field of near-death studies, public interest seems to have waned, agents are refusing to represent authors, and the newest publications languish in bookstores. The public seems to be saying, "I've heard it all." But in my view, they haven't. What I think they've had enough of is the basic mythology. What they haven't discovered is how the recent work in the field deviates from that mythology, and, in doing so, challenges not only the early work but also some fundamental assumptions of science itself.

Another likely factor in waning book sales is the economy. The upshot, I've learned, is that publishers are less committed to authors than to the large bookstore chains that will decide whether or not to sell a particular book. Both researchers and experiencers seeking the satisfaction of getting the word out or completing their promise to God or in some way giving the world something to think about that is well worth knowing must now choose between compromising their integrity to satisfy commercial publishers or maintaining their integrity and self-publishing - which more and more authors are choosing to do.

In either case, to promote sales, experiencers in particular feel intense pressure to exaggerate their claims. Added to this pressure to sensationalize is the religious factor: If an NDE follows along and further clarifies tenets common to a particular religious order or denomination, the publication and its author are very likely to be supported by the strength and power of that denomination. The same is true regarding tenets of mysticism or spirituality or esoteric traditions. In other words, the author who stays within the boundaries of one's faith or philosophy, even without realizing it, is likely to garner the supportive power of one's faith or philosophical group. I have often seen this phenomenon happen - with groups as disparate 
in values and beliefs as the Mormon church, evangelical Christians, and proponents of nondenominational spirituality. Each group believes its respective NDE and NDEr confirms the group's cosmology.

Another tactic that boosts sales is authors claiming to "break new ground" through their NDEs and/or their resulting insights. Very often they make this claim without acknowledging - probably without even realizing - that other experiencers had the same or similar revelations long before. Messages from new authors often are really not new.

Meanwhile, some authors perpetuate sales based on factors like name recognition rather than work that represents current perspectives in the field. Moody, for example, continues to draw huge crowds, his first book a perennial bestseller, despite his work now being subject to challenge and his classical NDE model being no longer recognized as accurately representative of NDEs.

Nothing I have said is meant to hurt anyone or point fingers of blame. My purpose is to promote a larger and, I believe, more accurate perspective. Research has established the NDE phenomenon, which includes the experience, the aftereffects, and the implications, as an actual and widespread phenomenon of great diversity and complexity. No single experiencer, no matter how good a speaker or how personally charismatic; no single case; no font of wisdom nor depth of revelations received; even begins to address or reconcile the complexity of the subjects on which the phenomenon touches. These subjects include what happens to people (and other animals) at and after death, whether there is a God, heaven and hell, suicides, murder, children's cases, angels and demons, reincarnation, the value of religious dogma, differences between religions, life purpose, and how people are changed psychologically, socially, spiritually, even physically by experiences like NDEs.

These are deep, heavy issues, to which most people want answers yet no single NDEr can supply those answers!!! The power of the neardeath phenomenon and what it can tell humanity can best be found in a synthesis, or summary of the many. This is the work of large-scale investigation and research like what I and others have done. True, just being around an experiencer, or reading experiencer books, can be life-changing; I acknowledge and affirm that point. But transferring to any experiencer the role of speaking for everyone else or being the best speaker or having the most to say or holding the record for the most harrowing case or being the most angelic or gifted or blessed or 
verified or stunning, is tantamount to self-deception - and to perpetuating misinformation on what, arguably, are life's most important questions.

It is the sum of the many that speaks loudest and most accurately if less sensationally. Although individuals can and do reach into a reader or listener's heart of hearts to inspire and uplift, I believe it is our job, each one of us, to question and to look around and consider what others have to say, as well. I've described cases in both ancient China and modern-day Africa in which NDErs pursued religious quests that, in my view, defy actual principles of spirituality (Atwater, 2007, pp. 368-370). Their followers, in the process of finding answers to questions about meaning and purpose in life, were all too willing to latch unquestioningly onto the NDErs' "truths." Findings about NDEs can help in this process, but they cannot determine for each person what is best to believe. I believe that determination is best achieved through not only comprehensive information but also rational and contemplative reflection.

Because this matter of proselytizing has become such a big issue, I seldom write Introductions any more for authors who request it, and I am far fussier about what I review or endorse. Just sending me a book without prior contact nets the author nothing. Certainly, only the experiencer can ever be the true authority on one's own experience. Among what I look for as a researcher is how the experiencer interprets what happened and what was revealed, and then how that material is expressed. I've found many of today's NDErs are far too willing to come across as blanket authorities on the subject, and they are equally much too anxious to present "one-size-fits-all" answers to life's greatest questions. I understand this propensity in context with what was actually revealed to them; they desire to remain loyal to what they garnered. But sharing that revelation and then giving talks and workshops that extend and dramatize that revelation - well, I cringe sometimes and hold extra tight to the chair.

I also get queasy sometimes about what NDErs tell people, even that all is forgiven after death. That mantra does not mesh with broadbased research in the field. There is far more diversity than that, and no one way things happen.

In the end, I believe people are best off when they remain open regarding answers to life's deepest questions. As the economy tightens, life can get scary, and people sometimes seek security in simplistic answers. I grew up during Pearl Harbor and its aftermath. 
With so many friends and neighbors dying, the war all around me, I found inspiration in nature, the people of our small community in southern Idaho, and the love that spread out its wonder from every leaf, rock, stalk of celery, and hug. Books were everywhere. Even when folks had hardly a dollar to spare, there were books, radio shows, discussions, debates, questions. We talked to each other, and we learned whatever we could - about solutions, about life, about our evolving understanding of God. This is the kind of world I believe best serves everyone.

\section{References}

Atwater, P. M. H. (2007). The big book of near-death experiences. Charlottesville, VA: Hampton Roads. 